Annals of Warsaw University of Life Sciences - SGGW

Land Reclamation No 45 (2), 2013: 227-234

(Ann. Warsaw Univ. of Life Sci. - SGGW, Land Reclam. 45 (2), 2013)

\title{
Investigations of re-hydration increase of dried sludge
}

\section{PIOTR WICHOWSKI ${ }^{1}$, TOMASZ ROZBICKI ${ }^{2}$}

${ }^{1}$ Department of Civil Engineering, ${ }^{2}$ Department of Hydraulic Engineering,

Warsaw University of Life Sciences - SGGW

\begin{abstract}
Investigations of re-hydration increase of dried sludge. The main aim of the research was to determine a susceptibility of a dried sludge to a re-hydration increase. The paper presents the results of investigations for a sludge which had been dried to ca. $86 \%$ of dry mass and stored in an airy place under roof during 2.5 years. As well, trials were carried out for a completely dried sludge $(0 \%$ of water), stored outside under roof as well as inside in a laboratory room. To determine a maximum level of humidity increase, the results of re-hydration increase were presented for a sludge stored in conditions of capillary ascent. Additionally, a density, porosity and bulk density were determined for the investigated sludge.
\end{abstract}

Key words: sludge, hydration, storage

\section{INTRODUCTION}

The final recycling of sludge causes a lot of problems. According to the 2014 State Plan of Wastes Management, the preferable form of neutralization of wastes are thermal methods (P.M. 2010, Nr 101, poz. 1183). The sludge secreted during a sewage purification is characterized with very high hydration, rising $99.5 \%$ for biological wastes. The natural form of their processing is a hydration reduction, which leads mainly to volume reduction, according to the scheme shown at the Figure 1:

If thermal methods of wastes management are considered, the incineration of sludge after its previous drying seems

$$
\begin{gathered}
\text { excessive sludge }-99 \% \text { of water, } 1 \mathrm{~m}^{3} \\
\Downarrow \\
\text { concentration }-96 \% \text { of water, } 0.25 \mathrm{~m}^{3} \\
\Downarrow \\
\text { dehydration }-80 \% \text { of water, } 0.05 \mathrm{~m}^{3} \\
\Downarrow \\
\text { drying - } 10 \% \text { of water, } 0.00625 \mathrm{~m}^{3} \\
\Downarrow \\
\text { incineration }-0 \% \text { of water, } \sim 0 \mathrm{~m}^{3} \\
\text { (small amount of ash) }
\end{gathered}
$$

FIGURE 1. An example of changes in hydration level and in volume of sludge on each stage of the sludge processing

to be a model solution (Pajakk 2006). According to the directives of European Union and the State Plan of Wastes Management, at the stage of planning, a lot of sewage treatment plants made the decision to build a sludge drying rooms (Tunia and Nowak 2006) with the assumption that it will be burnt in existing heat and power stations or cement plants. In the meantime a rigorous acts concerning installations to incineration of wastes were introduced (Law Gazette 37/2002, 95/2011). They significantly hinder the burning of wastes along with other materials in existing objects and force to built waste incineration plants. Such investment is expensive and causes serious social fears (Piecuch 2000). Currently, the dynamics of building of incineration plants seems to be lower than 
it was previously assumed. This situation causes that there are lying significant amounts of a dried sludge which cannot be treated by incineration. As a result, the dried sludge must be gathered to be burnt in the future. A long-time storage of the sludge can lead to a situation that its humidity rises again. The main aim of the investigations presented in the paper was to determine the susceptibility of a dried sludge to a re-hydration increase.

\section{MATERIAL AND METHODS}

A dried sludge from a municipal waste treatment plant was investigated. A technological process of a sludge drying consists of the following elements (Kalinowska 2007): film-type evaporator, squeezer, belt dryer and grinder.

After a mechanical dehydration on filter presses, the sludge (in which ca. $23 \%$ is a dry mass) goes to an evaporator, where is spread into a thin film and initially dried to a dry mass content of ca. $45 \%$. A staging post of the drying is a squeezing of the sludge on a sieve. The 8-mm gap sieve allows to obtain sludge threads which can break due to the gravity force and fall onto a conveyor belt transporting them to a belt dryer. The sludge must stay in the dryer no shorter than $40 \mathrm{~min}$. The effect is an increase of dry mass content to the level of ca. $87 \%$. The last element of the process is a grinder which allows to reduce the threads length and forms so-called dry sludge granules. The dried sludge is shown at the Figure 2.

To protect the dried sludge against atmospheric conditions, it can be stored in silos. In such case, a control of oxygen

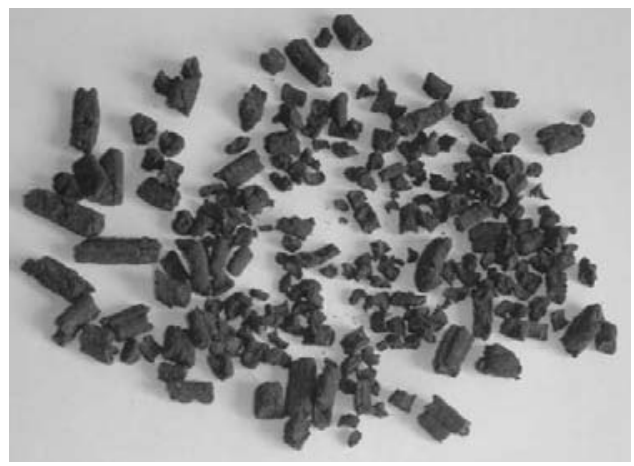

FIGURE 2. Dried sludge

and carbon monoxide content is necessary to avoid a self-ignition or possible explosion. Due to costs, the sludge is rather stored on a hardened foundation under roof in an airy place. To imitate such storage conditions, the sludge (in amount of ca. $1 \mathrm{~kg}$ ) had been dried in a greenhouse and then placed on an impermeable foundation in a meteorological box put on a terrain. The sludge was stored between years 2007 and 2009. The investigations were carried out in June, July and September of 2007, then in Decembers of 2007-2009, i.e. in the period which is characterized by relatively low values of temperature and insolation as well as high air humidity. Basing on the data registered on the weather station of WULS, the average air temperature, humidity and precipitation sum were determined in the day preceding the sampling. Additionally, at the end of January and the beginning of February 2013 tests were carried out for the sludge evaporated to dryness ( $0 \%$ of hydration) and stored outside in a meteorological box as well as in a laboratory room.

The investigations included determination of a dry mass content which consisted in evaporation of a sample to 
dryness in the temperature $105^{\circ} \mathrm{C}$ and in determination of a sample mass reduction according to the European standard (PN-EN 122880:2004). In certain chosen samples a content of organic and mineral substances in the sludge was also determined. It consisted in burning of a sample in the temperature $550^{\circ} \mathrm{C}$, weighing of the remains from ignitions of the sludge (mineral remains) and determination of the mass difference before and after the ignitions according to the European standard (PN-EN 122879:2004).

Causes of improper storage of the sludge are possible to find in practice. Due to large amounts of a dried sludge and lack of possibility to burn them, the sludge is stored on non-roofed store place. An improper storage leads to the sludge sinking during intensive rain or snow. Therefore, experiments were carried out concerning in determination of a hydration increase in a sludge stored in the conditions of capillary ascent. In order to do this, the sludge was evaporated to dryness in the temperature of $105^{\circ} \mathrm{C}$ and inserted to soil sampling cylinders with the capacity of ca. $95 \mathrm{~cm}^{3}$ (diameter $4.8 \mathrm{~cm}$, height $5.4 \mathrm{~cm}$ ), which then were put into a vessel with water (Fig. 3 ) what enabled a free capillary ascent. There was a filter paper under the cylinder which prevented from losses of the sludge during sampling. There was as many cylinders prepared as the tests carried out. As soon as the gravity water flew out, the sample hydration was started to determine.

The sludge re-hydration depends on its porosity. The tests of unit and volumetric (bulk) density of the sludge were carried out. The knowledge of these den-

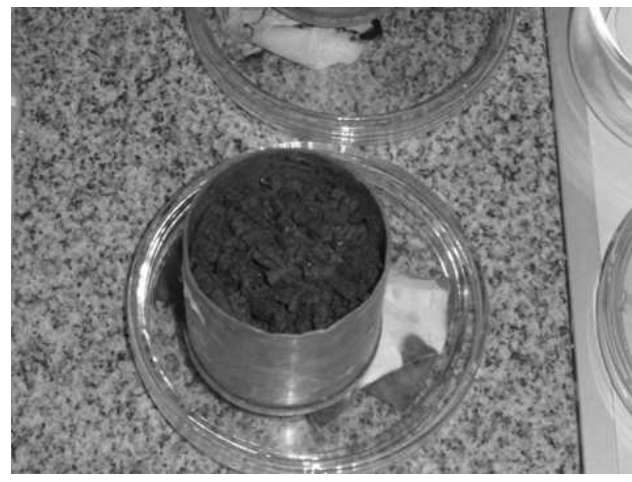

FIGURE 3. The sludge in soil sampling cylinders

sities enables to determine the porosity according to the Polish standard (PN-76/06714/06-09). The sludge density was determined according to the European standard (PN-EN 1097-7:2001) - with the use of a pycnometer and denatured alcohol. A unit density is a quotient of a dry mass of the sludge evaporated to dryness in the temperature of $105^{\circ} \mathrm{C}$ to the sample volume which does not include pores volume - neither spaces inside of each granule of the sludge nor spaces between granules. A volumetric density is defined as a quotient of a sample mass to its volume.

\section{RESULTS}

Figure 4 presents the results of investigations of hydration variability of a sludge dried in a belt dryer and stored outside on an impermeable foundation under roof in an airy place.

Figure 5 shows that a re-hydration is small if the sludge is stored properly. If the sludge hydration was average (ca. $13.8 \%$ of water), the highest average re-hydration was observed in December 2008 and it was $16 \%$. Thus, the maximal 


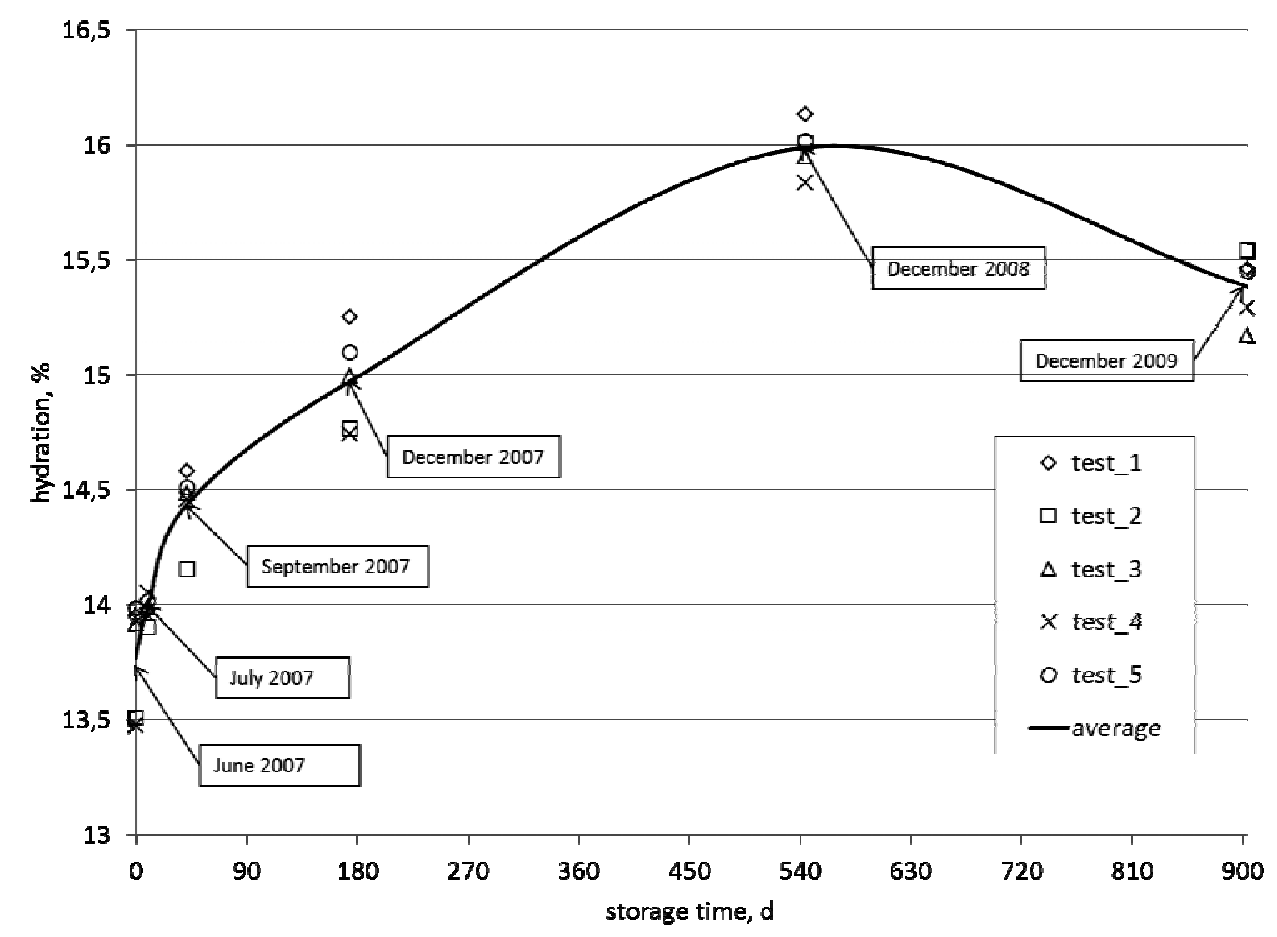

FIGURE 4. Changes of hydration of the dried sludge stored between years 2007 and 2009

hydration increase was $2.2 \%$. In the ana- as in the laboratory room, are shown at lyzed period the hydration was stable. the Figure 5. There is visible that the The meteorological conditions preced- humidity increase in the sludge stored ing the sampling are shown in Table 1.

The hydration changes in the sludge evaporated to dryness and stored in the free air in a meteorological box, as well tions were carried out in a period when

TABLE 1. Meteorological conditions in the day preceding the sampling

\begin{tabular}{|l|c|c|c|c|c|}
\hline \multirow{2}{*}{ Sampling date } & \multicolumn{2}{|c|}{$\begin{array}{c}\text { Average temperatu- } \\
\text { re }(T)\left[{ }^{\circ} \mathrm{C}\right]\end{array}$} & $\begin{array}{c}\text { Relative humidity } \\
(f)[\%]\end{array}$ & $\begin{array}{c}\text { Relative humidity at } \\
13 \text { o'clock }(f 13)[\%]\end{array}$ & $\begin{array}{c}\text { Precipitation sum } \\
(\Sigma P)[\mathrm{mm}]\end{array}$ \\
\cline { 2 - 3 } & night & day & 59 & 41 & 11.7 \\
\hline 27.06 .2007 & 12.2 & 17.0 & 63 & 34 & - \\
\hline 19.07 .2007 & 21.2 & 26.2 & 79 & 64 & - \\
\hline 13.09 .2007 & 13.1 & 14.1 & 94 & 90 & - \\
\hline 18.12 .2007 & 1.0 & 1.2 & 79 & 67 & 1.3 \\
\hline 23.12 .2008 & 1.8 & 2.2 & 85 & 86 & 4.6 \\
\hline 17.12 .2009 & -11.8 & -11.5 & & & \\
\hline
\end{tabular}




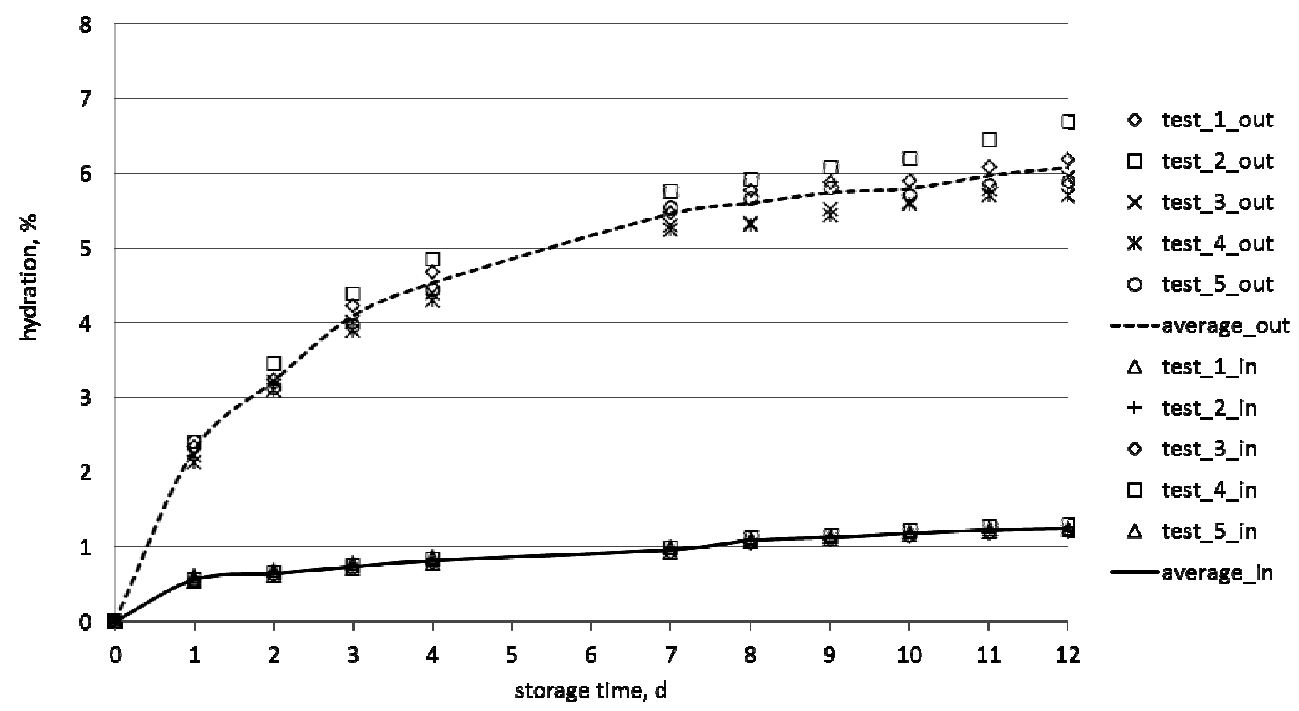

FIGURE 5. Changes of humidity of the sludge evaporated to dryness (in the temperature $105^{\circ} \mathrm{C}$ ) stored outside and in the laboratory room

flats are centrally heated, so there was the room temperature (i.e. ca. $20^{\circ} \mathrm{C}$ ) and relative humidity ca. $50 \%$ in the laboratory. During the investigations, i.e. from 21.01.2013 till 02.02.2013 the average air temperature outside was $-4.3^{\circ} \mathrm{C}$ and the average relative humidity $-96.4 \%$. After 10 days from the test beginning the humidity of the sludge stored outside was ca. $5.8 \%$, whereas that stored in the laboratory room $-1.2 \%$. Then, a slow long-lasting increase of the sludge hydration was observed. After a 90-day storage the humidity of the sludge stored outside was $8.1 \%$, whereas that stored in the laboratory room $-2.4 \%$.

Figure 6 shows changes of hydration in the sludge stored in conditions of capillary ascent. There is visible that the most intensive increase of the humidity was in the first day, when the average hydration increase was ca. $22 \%$. Then slower and slower increase was observed and finally
- its stabilization after ca. 10 days on the level of $34.5 \%$.

The investigations of unit and bulk density as well as porosity of the dry sludge are shown in the Table 2. In the sludge used to the tests, the average percentage mass fraction of mineral to organic substances is $40 / 60$. The proportion was stable during storage what shows that the sludge stabilized itself properly.

\section{SUMMARY AND CONCLUSIONS}

The average density of a dried sludge used to the investigations was $1.66 \mathrm{~g} /$ $/ \mathrm{cm}^{3}$, the average bulk density $520 \mathrm{~kg} /$ $/ \mathrm{m}^{3}$, the porosity - ca. $68.5 \%$. The bulk density depends on the granule size. As it can be seen at the Figure 2, the granule size in a given sample of the sludge can be very various, additionally it depends on a technology of drying, a gap of sieve 


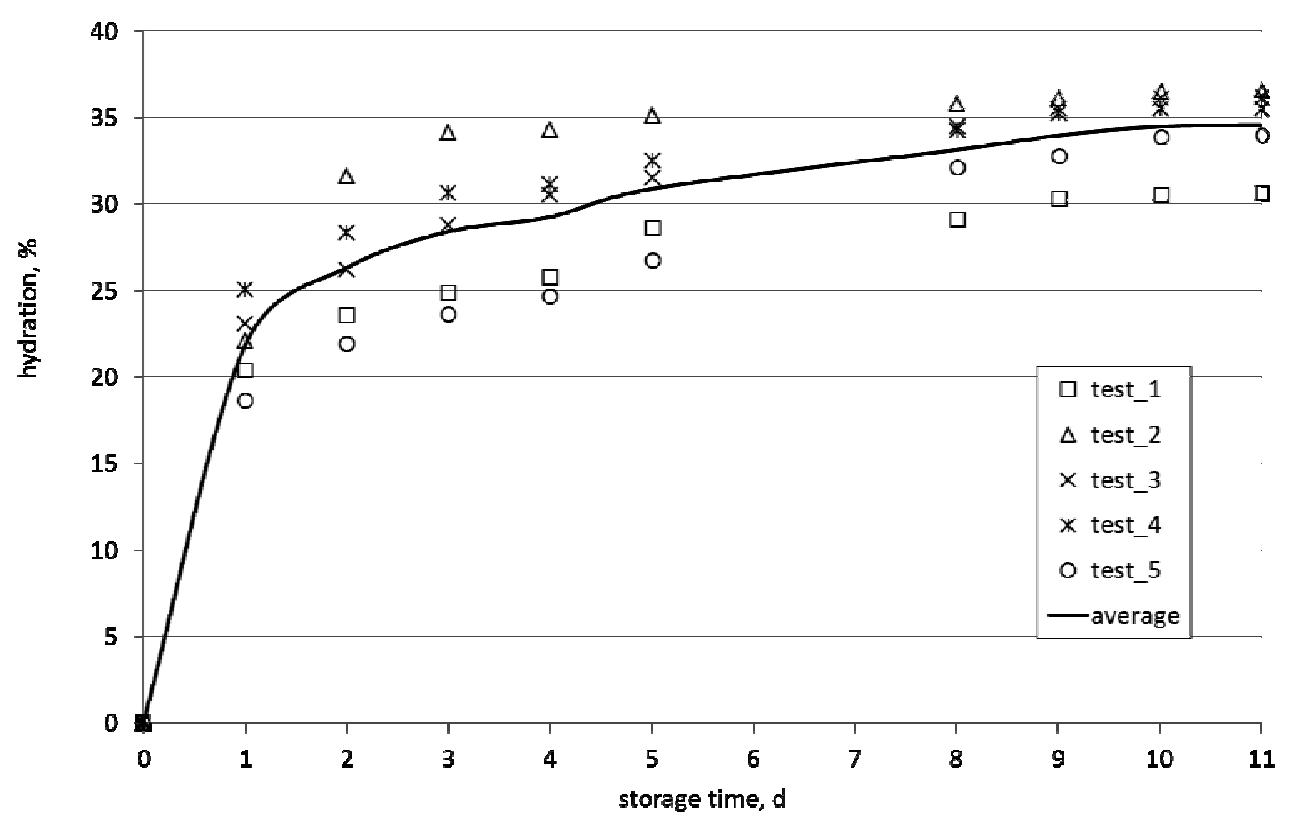

FIGURE 6. Changes of hydration of the sludge evaporated to dryness (in the temperature $105^{\circ} \mathrm{C}$ ) stored in conditions of capillary ascent

TABLE 2. Results of tests of unit density, bulk density and porosity of the sludge dry mass

\begin{tabular}{|c|c|c|c|c|}
\hline Item number & Date of test & $\begin{array}{c}\text { Unit density } \\
{\left[\mathrm{g} / \mathrm{cm}^{3}\right]}\end{array}$ & $\begin{array}{c}\text { Bulk density } \\
{\left[\mathrm{g} / \mathrm{cm}^{3}\right]}\end{array}$ & Porosity [\%] \\
\hline 1 & 29.01 .2010 & 1.62 & 0.51 & 68.33 \\
\hline 2 & 11.02 .2010 & 1.62 & 0.51 & 68.47 \\
\hline 3 & 12.02 .2010 & 1.68 & 0.51 & 69.48 \\
\hline 4 & 15.02 .2010 & 1.68 & 0.53 & 68.46 \\
\hline 5 & 16.02 .2010 & 1.68 & 0.53 & 68.38 \\
\hline 6 & 17.02 .2010 & 1.68 & 0.53 & 68.15 \\
\hline 7 & 18.02 .2010 & 1.68 & 0.54 & 68.09 \\
\hline$\times$ & Average & 1.66 & 0.52 & 68.48 \\
\hline
\end{tabular}

in the squeezer, degree of drying, etc. carried out along with an incineration The bulk density determined through - economically justified (Bien and Wysthe investigation is thus not a universal talska 2008). It is recommended that the value, however it can serve as a refer- dried sludge is immediately burnt. Lack ence value, e.g. to estimate a load ca- of an appropriate amount of incinerapacity and volume of devices delivering tion plants with relatively large amount sludge to incineration plants. The sludge of drying rooms extorts to store a dried drying process is very expensive, but if sludge to burn it later. An improper stor- 
age can affect the increase of its re-hydration. This increase is an unfavorable effect because it worsens the energetic balance of incineration and then - an energy consumption of the whole process. A sludge can be autothermally incinerated if its calorific value is ca. $9 \mathrm{MJ} / \mathrm{kg}$ what corresponds to a sludge hydration equal ca. 10\% (Steinbacher and Burchardt 2006).

The performed investigations allow to determine a potential re-hydration increase depending on the drying degree and conditions of storage. They show that the sludge evaporated to dryness is more prone to soak the humidity from environment than the sludge dried to a dry mass content at the level of $86 \%$ (the sludge humidity obtained in a drying room). The storage conditions also affect the re-hydration increase. The sludge evaporated to dryness does not significantly soak the humidity from the air if stored in well aerated space in a room temperature. Higher increase of re-hydration is observed after storage outside under roof, the highest - if the sludge is exposed on direct action of atmospheric conditions.

Basing on the performed investigations, it can be concluded that:

- The sludge dried to the level of water equal ca. $13.8 \%$ and stored under roof on a hardened ground does not soak significantly the humidity from the atmospheric air. During 2.5-year storage the maximum increase of the volume was $2.2 \%$.

- In the sludge evaporated to dryness ( $0 \%$ of water) and stored under roof on a hardened ground, there was observed that the humidity degree in- creased to ca. $5.8 \%$ after 10 days of storage and to $8.1 \%$ after 90 days.

- In the sludge evaporated to dryness and stored in a heated laboratory room in the temperature ca. $20^{\circ} \mathrm{C}$ the humidity increased to ca. $1 \%$ after 10 days of storage and to $2.4 \%$ after 90 days.

- The sludge evaporated to dryness stored in the conditions of capillary ascent reached the level of the humidity equal ca. $34.5 \%$ after 10 days of storage. A longer storage did not cause a further increase of the humidity. The most intensive increase of re-hydration was observed during the first 24 hours and was equal $22 \%$.

\section{REFERENCES}

BIEŃ J., WYSTALSKA K. 2008: Trends of development in sludge processing technology. Water Supply and Sewage Systems 10(56): 30-31.

KALINOWSKA M. 2007: Investigations of effectiveness of sludge processing in chosen devices of technological system of Sewage Treatment Plant Warsaw-South. Master thesis, WULS, Warsaw.

State Plan of Wastes Management 2014: (Resolution 217 of the Council of Ministers from 24.12.2010) M.P. $2010 \mathrm{Nr} 101$, poz. 1183.

PAJAূK T. 2006: Drying and thermal processing of communal sludge. Water Supply and Sewage Systems 4(26): 41-43.

PIECUCH T. 2000: Thermal wastes utilization. In: Annual Set The Environment Protection. Middle Pomeranian Scientific Society of The Environment Protection. Koszalin: 11-37.

PN-EN 12880:2004. Characterization of sludges. Determination of dry residue and water content. 
PN-EN 12879:2004. Characterization of sludges. Determination of the loss of ignition of dry mass.

PN-EN 1097-7:2001. Tests for mechanical and physical properties of aggregates - Part 7: Determination of the particle density of filler - Pyknometer method.

PN-B-06714-06:1976. Mineral aggregates. Testings. Determination of apparent density in graduated measuring cylinder.

PN-B-06714-09:1976. Mineral aggregates. Testings. Determination of porosity.

Order of Ministry of Economy on 21 March 2002 on requirements concerning thermal processing of wastes (Law Gazette 2002, № 37, pos. 339 incl. further changes).

Order of Ministry of Environment on 22 April 2011 on emission standards from installations (Law Gazette 2011, № 95, pos. 558).

STEINBACHER S., BURCHARDT H. 2006: Systematical analysis of wastes recycling on example of a German project. Steinbacher-CONSULT, Germany. Materials from the seminar "Disintegration of Sludges". Gdańsk Water Foundation, Gdańsk.

TUNIA A., NOWAK A. 2006: Sludge solar drier on the sewage treatment plant in Rzeszów. Exploitator Forum 6: 60.
Streszczenie: Badanie wtórnego wzrostu uwodnienia wysuszonego osadu ściekowego. Głównym celem badań było określenie podatności wysuszonego osadu ściekowego na wtórny wzrost uwodnienia. W artykule przedstawiono wyniki badań dla wysuszonego osadu ściekowego do ok. $86 \%$ suchej masy składowanego pod zadaszeniem w przewiewnym miejscu przez okres 2,5 roku. Wykonano także próby dla osadu wysuszonego do stałej masy ( $0 \%$ wody) i składowanego na zewnątrz pod zadaszeniem oraz wewnątrz w pomieszczeniu laboratoryjnym. Celem określenia maksymalnego poziomu przyrostu wilgotności przedstawiono wyniki wzrostu uwodnienia osadu składowanego w warunkach podsiąku kapilarnego. Dodatkowo dla badanego osadu wyznaczono gęstość właściwą, gęstość objętościową oraz porowatość.

Stowa kluczowe: osady ściekowe, uwodnienie, składowanie

MS. received in December 2013

\section{Author's address:}

Piotr Wichowski ${ }^{1}$, Tomasz Rozbicki ${ }^{2}$

${ }^{1}$ Katedra Inżynierii Budowlanej

${ }^{2}$ Katedra Inżynierii Wodnej

Wydział Budownictwa i Inżynierii Środowiska Szkoła Główna Gospodarstwa Wiejskiego

ul. Nowoursynowska 159

02-776 Warszawa, Poland

e-mail: piotr_wichowski@sggw.pl tomasz_rozbicki@sggw.pl 